\title{
Introduction
}

The opening up of holy orders to women by the Church of England has been documented by numerous books and journal articles from the 1960s onwards (see for example Gill, 1994; Robbins, 2008). Within the Church of England there is a threefold order of ministry: deacons, priests and bishops. Before the ordination of women to the diaconate the focus was on two main issues, the role of deaconesses (Fullalove, 1987a, 1987b) by some considered to be commensurate with the role of deacon for women, although deaconesses were not permitted to fulfil the same roles as deacons; and the arguments for and against women deacons (ACCM, 1991). Following the ordination of women as deacons (1987) the focus changed, research on deaconesses ebbed away (although some women remained deaconesses as they considered this to be 'their calling') and the focus became the experiences of women deacons and the arguments for and against women priests. The research on women deacons took two main routes. The first was a focus on the women telling their own stories through interviews and completing questionnaire surveys (Treasure, 1991; Francis \& Robbins, 1999) the second was a focus on a theology of the permanent diaconate which, at this point in time, the Church of England had effectively created (Hall, 1992). In 1994 the first women were ordained priest, the legislation having passed in 1992, and the consideration of the theology of a permanent diaconate reduced in prominence and women ordained to the priesthood could now celebrate communion, give absolution and blessings. There are a number of reasons why researchers have been drawn to clergywomen in the Church of England not least because this is one of the last areas in our society where the role has only recently opened to women (see for example the work of Jones, 2004). Indeed it is only in 2015 that the first women have been appointed to the episcopate, the legislation having passed in 2014. Therefore, the Church of England is still engaged in 'firsts' with regards to the ministry of women. This has 
given researchers the opportunity to explore how the entry of women into holy orders has been experienced by the women who are called to ministry and to consider how their presence has changed our understanding of ministry.

The situation of clergywomen within the Church of England is unique because of the existence of The Act of Synod (1993) which was only rescinded in 2014 as part of the legislative process that removed the barriers to women bishops. This church legislation effectively put in place the concept of the two integrities whereby clergywomen could be discriminated against on the grounds of their gender (see Furlong, 1998). The Church of England, alongside other religious organisations is exempt from the 2010 Equality Act and the precursors to that Act. The legislation concerned with the appointment of women bishops, while moving away from laying down formal provisions, still offers safeguards for opponents, thus arguably leaving significant avenues for continued institutional discrimination ${ }^{1}$. The arguably unique position that this places Church of England clergywomen compared to those in other Christian denominations as well as in comparison to women in other professions in the UK has been discussed elsewhere (Greene \& Robbins, 2015; see also Bagilhole, 2006).

Those who have conducted research among clergywomen have utilised a variety of theoretical and conceptual frameworks to attempt to explore the experiences of clergywomen entering this male sphere. For example Acker's $(1990,2006)$ theory of gendered inequality regimes within organisations (Greene \& Robbins, 2015); Butler's concepts of 'gender performance' (Bagilhole, 2002, 2003), and notions of the 'gender paradox' (McDuff, 2001) to name a few. Others such as Niemela (2011) have argued that clergywomen act as 'agents of change' by their entry into priesthood. A consistent observation in all this research is that

\footnotetext{
${ }^{1}$ Suggestions are that the ability to request male priests and bishops to look after parishes will be guaranteed by principles set down in a declaration, with disputes ruled on by an independent reviewer. However these are not formal clauses of the legislation, and opponents will have to trust that their views will be considered.
} 
clergywomen are in an unusual situation as far as their 'employment' is concerned and particularly within the Church of England where discrimination on the grounds of gender remains permissible.

The aim of this study is to listen carefully to what the clergywomen themselves say using a thematic analysis of interviews to hear how they understand and experience their ministry within the Church of England.

\section{The Research Study}

\section{Methodology}

The study employs a thematic analysis of twenty-one interviews. In conducting the interviews, the researchers' aim was to explore latent themes within the interviews, that is exploring the underlying patterns in relationship to issues that clergywomen may face in their ministry. In line with the approach taken by Martin (2001), in her research exploring women's perspectives on male behaviour in commercial organisations we deliberately began the conversations as general enquiries into the life histories of the women, and their perspectives on their clergy work, without specifically utilizing gender as a construct in order to avoid focusing from the start on the problems they faced. Our main interest was in paying attention to the voicing of the perspectives, interpretations and experiences of the women. However we also had an intention within our overall research questions, to try and assess the extent of their experiences of differential treatment as women. If perspectives/opinions on these issues were not raised spontaneously by the interviewees, we pressed them later in the interviews on this point. Our intention was not to provide research that could be generalized across the whole population of Church of England clergywomen, and certainly not across the Church of England as a whole. We are also aware that we do not have interviews with clergymen to directly compare our interview data with, which might offer some perspective 
on whether the women's views are gender specific. However, given the unique situation of clergywomen within the Church of England, we feel that it is important to capture the experiences of the women as a separate group. In this regard we accept Martin's premise of feminist standpoint theory that 'accounts of the less powerful offer knowledge of the more powerful' (2003: 593). We also feel that in providing an exceptional case, the interview data is useful to analyses of other male dominated professional contexts, providing insight into processes and mechanisms that may not be as easily discernible under more moderate conditions (Creed at al, 2010: utilising Eisenhardt, 1989).

\section{Participants}

All twenty-one women are or have been in full-time stipendiary parochial posts within the Church of England. The participants are aged between 29 and 63 years. Four were ordained priest in the 'first wave' of ordination in 1994. Approximately half of the participants were contacted through an email approach from the national officer of the trade union Unite, (an email was sent to all female members of the sub sector of the union); some through snowballing on from that sample; and some through personal contacts of the authors. Table 1 presents a summary of the participants' age, marital status, year of ordination and dependent children. Overall, despite generaliseability not being of primary concern, our sample included a wide spread across the population of Church of England parish clergy. In terms of geographical representation, we interviewed women who had experience of clergy appointments in a broad range of dioceses covering all the regions of the UK and 22 out of the 44 dioceses in England. In addition the sample included 10 serving in rural parishes and 11 serving in urban parishes. The age range of our sample was reflective of the overall population of clergywomen (as seen in large-scale surveys Robbins and Francis, 2010; Robbins et al, 2010; Robbins, 2008) with most being in their 50s and 40s. All women in our 
sample were white, this reflects the fact that $97 \%$ of all stipendiary clergy within the Church of England are white (Archbishops Council, 2013).

-insert table 1 about here-

\section{Data collection}

The semi-structured interview was designed as a guide to facilitate hearing the clergywomen's voice. Broad interview guides explored a number of features of their life histories and ministry work including: call to vocation; previous work/careers; selection and training experiences; career orientations; reflections on work-life balance; levels of autonomy, security and remuneration within their work; satisfaction with their ministry; levels and causes of stress; experiences of gender discrimination; and relationships with congregations, peers, and senior Church members.

\section{Researchers' perspectives}

The first author has been working with clergywomen since 1992 when she undertook a large scale survey of women deacons in the Church of England for her doctoral thesis. This interest was sparked through speaking to women who were seeking ordination in the Church of England at a time when they could not be priested. The second author is a Roman Catholic, and an employment relations academic who is particularly interested in work where calling and mission are central. Neither author is ordained or is seeking ordination, Peyton and Gatrell (2013: 8-9) discuss the strength of 'critical distance' that may come from this. We are not clergy, and interestingly some of our interviewees viewed our lack of connection to the Church of England positively in that they did not want their views conveyed to those in senior positions within the Church such as their archdeacon or bishop. The researchers own biases were, as far as possible, dealt with through discussions with colleagues familiar with the methodology being employed but unfamiliar with the subject matter. The invitation to the 
clergywomen to re-engage with their printed transcripts (discussed in the next section) also provided for clarification that enabled the researchers to stay more faithful to the voices of the clergywomen themselves.

\section{Procedure}

A total of twenty-one semi-structured interviews were conducted. The length of the interviews ran from between one and a half hours and three hours. The majority of interviews were conducted in the homes of the clergywomen, and so we shared the experiences of Peyton and Gatrell's (2013: 34) 'ethnography at the vicarage'. All the interviews were recorded with the permission of the participants and transcribed. In addition, as an 'authenticity check', the participants were sent their transcriptions and invited to comment and ensure that no identifying material was included.

\section{Data analysis}

Both researchers read and re-read the transcripts and discussed their content. The first author then re-read the transcripts in full and identified themes using key words. Each transcript was then re-read to see if the themes could be identified in each of the interviews. If the theme could not be found in more than ten of the interviews it was dropped. From this process three linked themes emerged.

\section{Findings}

Three latent themes emerged from the data: perceptions of difference between explicit and implicit opposition; differences in how their ministry is perceived by others; and tensions in ministry between their internal and their external worlds. 
Although all three themes clearly emerge from the data it is evident that both the first and second themes impact on the third theme. The external and internal tensions expressed by the clergywomen flow from the opposition they experience and the way in which they 'do ministry'.

\section{Theme 1: explicit and implicit opposition}

Participants were asked a general question about whether they had experienced hostility or opposition to their ministry. When asked directly, very little was forthcoming, however the stories of opposition emerged during the course of conversations around other areas of ministry, in some instances almost as asides to illustrate a different point. What is clear is that all the women in the sample had experienced some form of opposition to their ministry because they are a female priest. The most common example of explicit opposition was the refusal of male peers or congregation members to take communion from them because they were women priests, which was mentioned by thirteen of the twenty-one interviewees. Other examples included one interviewee having been spat on in a cafe, another being verbally attacked at a training event, and many receiving rude and threatening emails and telephone calls, the fact they were women priests being the motivation for the incident. There were also numerous examples of what was considered as unacceptable behaviour from both parishioners and clergymen, for example sexist jokes, banter and teasing and inappropriate physical touching. Two interviewees had experienced a parishioner making an explicit and unwanted sexual advance. However, for most it is the implicit opposition that is more difficult to deal with as Rebecca (ordained 2000) states:

... there is the subtle undermining by those who have not declared themselves, its generally the conservative evangelicals, who haven't declared against women in ministry but display a very patronising manner... 
She goes onto say:

It can be a drip, drip of someone not declaring themselves to be against women but finding every opportunity to criticise, belittle, and obstruct.

Rebecca (ordained 2000) said she was not prepared for opposition to her ministry: ... it didn't prepare me for the bigoted response, from those who were ordained, but who were against women's ministry. ... I have had significant difficulty with other clergy since I've been here.

Explicit opposition of whatever form can, of course, be difficult to deal with, indeed, there seemed to be a general acceptance of this as an institutional norm, with a feeling from the women in our study that this was just part of their ministry. The instances of refusal to take communion, or even the directly abusive behaviour went largely unchallenged and unreported. The majority of participants report instances where they dealt with this opposition, usually by just getting on with their ministry which led to people 'coming round', often after a considerable period of time. The following two examples illustrate this point effectively for all the participants. The first is from Winona (ordained 2001):

I had one man in [parish name] when I first came who said 'I don't believe women should be priests and I will never receive communion from you. That was in October. The following Easter, after I had spent a lot of time with him and his wife, on Easter Sunday ... in front of everybody he put out his hands to receive communion.

The second from Josephine (ordained 2000):

When I first came to this church ... there were people in the congregation who didn't agree with a woman priest ... but they've all come round. I think the longest took six years for my last couple to come round but they all receive communion from me.

Katriona (ordained 2008) refers to it as people 'unbending': 
There's still a few people with deep-seated opinions which weren't particularly personal but ... you sort of live with and then to see those maybe sort of unbending which is lovely.

Theme 2: 'doing ministry' - how their ministry is perceived by others

The question was asked 'Do you think the church has changed as a consequence of women being ordained?' What was interesting was that almost without exception the clergywomen stated in some form that clergywomen were not better than clergymen at ministry, this seemed to be the implication they were taking from our question. Nonetheless their understanding of the impact clergywomen were making in ministry did come through in the stories that they reported of things that others had said to them. It was as if they were distancing themselves from saying they were different but were willing to pass this conclusion on if it was in someone else's words.

The women in Bagilhole's study (2006; 2003), a decade or so ago all felt that they were making changes in the Church - to the nature of priesthood, the use of language and symbolism, the style or working, and acceptance of women in the hierarchy (Bagilhole, 2006: 121). In accordance with Bagilhole's findings, most of our interviewees also felt that the Church was now more diverse, representative and egalitarian than it had been before 1994, and they welcomed the fact that women were now more accepted by both male clergy and congregations, and that there were now more opportunities for women in the Church, providing role models, and spaces to fulfil vocational conviction for girls and women within the lay membership. Additionally, like those in Bagilhole's study (2003; 2006), a smaller number felt that ways of working within the hierarchy had changed as consequence of women clergy, for example that there was felt to be more collaborative and consultative working (particularly between PCCs and clergy). In her review of research in the field, and 
based on her own empirical analysis of large-scale survey evidence of US congregations, Stewart-Thomas (2009) found that the presence of women clergy made significant differences to congregations, in particular the type of activities engaged in, finding for example that those led by women tended to engage in far more social service related programmes. There were also comments from our interviewees that the presence of women had a positive impact on congregations, for example:

We've had a lot of growth; a lot of new people have come in. It feels, they tell me it feels quite different... But I think there's a lot more reality about the life of the parish. We're hearing more stories about what it really happening to people. I don't get the feeling that we've got as many people coming in and putting on a Sunday face... it does feel more relaxed, there are more children around and there seem to be more men around...

However many of our interviewees were also acutely aware of the need to address concerns about the possible feminisation of clergy and of congregations. Some spoke of the way that they were aware that they needed to make deliberate efforts to avoid an over-feminisation of their own services and to avoid what one interviewee called a 'petticoat ministry'. As another reflected on the practice of her own Sunday services:

I try and keep the balance. I suspect that male clergy probably don't think about whether they're keeping the balance with involving women in worship. I suspect that it's only me that notices now, in my church... I'll say 'well we had me presiding, we had Lesley assisting, we had women reading the bible readings, we had a woman interceding and we had all women with the chalice and the bread, didn't you notice?' and they'll say 'No', and I'll think 'Good, they didn't notice'... I think 'Oh if they haven't noticed then there can't be anything wrong with it being all women, can there'? 
Another interviewee was aware of the need to make liturgy that was relevant and interesting to men, and particularly to boys, which she felt was not improved by the increase in the number of women clergy.

Overall, there was a common view that men and women brought different skills to their ministry, many of these based around stereotypes of female/feminine skills. Bagilhole (2006) focused on the way that clergywomen held different posts, did different types of work in different proportions, and took on different roles to men. The clergywomen in our sample were able to identify particular advantages that came to them as a consequence of being a woman, for example finding access easier to schools, hospitals, and the wider parish community. While a couple of interviewees were adamant that they wanted to be viewed in a gender neutral way and not as a woman priest, the majority were acutely aware of their gender difference, both positive and negative, and the need to either play this down, compensate for it, or emphasise its effects. For example, nearly all the clergywomen gave an example of bereavement where others said their presence as a female made a difference. For example Amanda (ordained 1994):

I always got the impression from people that they were pleased they'd be dealt with by a woman, and they were predisposed to be pleased because they thought we would be more approachable and more compassionate than some of the men.

Some the clergywomen who cited such cases implied that a clergyman could have been just as effective. For example Cathryn said:

I more often get the opposite, 'I'm glad that it's a woman doing this'. And I sometimes think that it's unfair to the men clergy. There is this perception that if you're a woman you're going to be very understanding and caring. But I know a lot of very caring and sensitive men. 
Amelia (ordained 2000) notes the underlying assumptions others have of her because of her gender:

I think there is sort of an automatic understanding that I might have some experience or understanding of children. Well, actually I'm a single woman and haven't had children of my own.

Whereas others noted that women sometimes just notice different things as Judith (ordained 2001) points out:

I remember going off on holiday having just done a funeral and saying to my boss who was a man 'would you go and see Mrs Whatsit' ... When I came back from holiday, he said 'I went ... she said to tell you she was eating well ... what's that all about?'... 'Do you know when I've done bereavement visits it's never occurred to me to ask if they're eating well'.... as a mum I suppose it's the first thing you think about.

\section{Theme 3: tensions in ministry}

The tensions created by explicit opposition to clergywomen tended to be dealt with by the clergywomen by talking with those concerned if that was possible. The tension exists in the way that the clergywomen differentiate between what they see as a genuine theological objection (although they do not hold such a position themselves) which they can respect and misogyny which has no place within the church. It is important to note that despite the fact that more than half of the interviewees indicated that they came from an Evangelical or Anglo-Catholic tradition, the institutional view of the two integrities ${ }^{\mathrm{i}}$ is not supported by any of the clergywomen. As two typical responses illustrate:

I think it's complete nonsense. If you have a human being with two integrities, they are fundamentally sick. And actually that's what's happened to the church (Julia ordained 1994) 
I think it's a load of nonsense; you can only have one integrity... But we can't go on like this forever; I can't continue to be a priest and not a priest, like Schrödinger cat alive and not alive... What hurts and what I struggle with at the moment is the sense that women are being blamed. (Amanda ordained 1994).

However, the tension is between their view of the individual and their view of the institution. While the majority of interviewees were wholly negative about the theology of the two integrities, most also claimed that people opposed to women's ordination should be accepted and accommodated rather than challenged. The view of Veronica (ordained 2002) was typical:

'there needs to be some provision within the Church for those people who do not accept women priests...I don't share their views but can respect that they hold them, and for the Church to just abandon them... is not being a loving sister or brother in Christ'

There is also tension in the way in which they are perceived to 'do' their ministry. The clergywomen were all aware that the expectations of others tended to be of traditional female strengths, the examples often cited were others seeing them as better at working with the bereaved and with children. Although the clergywomen seemed appreciative of the pastoral opportunities these expectations afforded them they were also conscious that this was unfair; unfair because as many pointed out clergymen are just as able to minister in these contexts. As Winona (ordained 2001) stated:

... because we are men or women that's immaterial, as far as I can see

There was also the tension of expectations of others of the traditional clergy family of vicar and vicar's wife, the expectation that because they were women they would do some of the tasks that a clergy wife would traditionally have undertaken; even though this model no 
longer holds true among clergymen (Muphy-Geiss, 2011). Our interviewees confirmed the prominence and expectation amongst congregations of the stereotype of the male priest who had a full time wife. The gender inequality of this was summed up by Veronica (ordained 2002):

...at Harvest festival it is the women who decorate the church, and then [I] was in there, [and] the women said that [X], the previous incumbent's wife used to help out decorating. [I] said 'Oh I will go home and let [my husband] know' and promptly left!

In a similar way Candice (ordained 2009) said:

... on the face of it sounds silly but I am frequently asked to make the tea and that sort of thing and they would never dream of asking my incumbent to make the tea Joan (ordained 2003) stated that:

To some extent being the woman there has been an assumption that the woman priest will want to organise the coffee morning or the jumble sale.

Some members of congregations respond to clergywomen by expecting them to fulfil both the role of vicar and vicar's wife as Veronica ordained 2002 notes:

They expect me to be the vicar and the vicar's wife in one person but they would never expect [name of husband] to do the things that their previous vicars' wives would do.

That these women did not have a traditional 'vicar's wife' to rely on and share some of their work also intensified the heavy workload that every interviewee referred to as the primary cause of stress in their ministry work. Nearly half the group of interviewees did not always take their day off every week, while over half did not take their yearly holiday entitlement. There were numerous examples of our interviewees feeling guilty because they did not spend enough time with their children and partners, not being able to sleep, suffering from mental 
health issues, periods of depression, family break ups, and general difficulty in coping with the pressure.

\section{Discussion}

Two issues of enquiry were highlighted from previous research; First has the ordination of women changed the ministry of the Church of England? Second, how do clergywomen understand their ministry? What has emerged from the interviews is a reluctance by the women to state outright that they bring difference to ministry, that they 'do' ministry differently. However, it is clear that for many of the women there are instances when they do, in fact, report doing ministry differently. This does lead to tension with the clergywomen agreeing that although gender is irrelevant in how well ministry is conducted nonetheless they come across expectations of themselves which are gendered. With regard to both the explicit and the implicit opposition the clergywomen report that the Church of England does not support them.

The first two themes to emerge from the analysis both illustrate the third theme of tensions in ministry in that there is a tension between those who openly declare themselves opposed to women's ministry and those who do not do so; there is also a tension between the expectations of the people among whom the women work, that their ministry will in some way be different because they are women and the view of the clergywomen that it is about the individual.

\section{Opposition to ministry}

Reflecting further on the women's stories, their descriptions of opposition were always recognisable as being of one of three types, implicit, explicit open to conversation, explicit and closed to conversation. The implicit opposition was seen as undermining of their ministry 
because it could not be effectively dealt with. Unsurprisingly it seems that the women found it very difficult to challenge behaviour that was demonstrating opposition to their ministry when it was being engaged in indirectly. This behaviour often led the women to feeling isolated and unsure how to tackle it. A number of the women reported their concerns that if they dealt with this in a way that might make them seem forceful or difficult it might result in making the situation worse.

With regard to explicit opposition, the women seemed to demonstrate a considerable amount of respect for those who were open about their objections especially if they continued to support the church and kept communicating with them and others in the community. Indeed, almost without exception, where this was the case the women report being able to build a good rapport with those who did not agree with the ordination of women and being able to accept their decision not to take communion from them because it was not felt to be a personal rejection of them and their ministry but rather a theologically informed position.

It is interesting to note that the language which the women used in discussing explicit and implicit opposition to their ministry was very different. Often when discussing open opposition the women used words like friendship and respect; whereas when discussing implicit opposition words like patronising and belittling. For the clergywomen who are dealing with opposition it is obvious that support from other members of their congregation is important. Although as Veronica commented this could sometimes not be helpful pastorally to the person who objects to their ministry, for example when she moved to a new post a female parishioner left the church because she could not accept a woman priest. This woman used to be on the PCC. Veronica made contact with her deliberately just to say that she understood her position; the woman was almost in tears, because the rest of the PCC and others in the parish were saying that she was acting stupidly, and she did not expect the only person to take her seriously to be Veronica. 
There were also those who reported that the opposition they experienced was explicit but there was no opportunity to interact with those who expressed this opposition. Karen (ordained 2004) illustrates this point by the following incident where someone shouted at her: '... are you one of those priestesses? You're the sort that's wrecked our church.'

The effect of the Act of Synod and the two integrities was to give permission to those who object to the ministry of clergywomen to do so overtly. The clergywomen seem to be able to deal with this if the opposition is expressed within the 'Christian values' of love and mutual respect. This is evidenced by a number of clergywomen themselves stating that whilst they may not agree with decisions some people reach they can respect them if they are honestly arrived at and openly discussed. It is those who object to their ministry but do not demonstrate this openness that the clergywomen find difficult to respect. For the women who experience this behaviour it can cause significant problems, not just the lack of recognition of their ministry but also on a practical level. For example take the case of Candice (ordained 2009) whose neighbouring parish priest will not reply to her emails. Her hope had been that using email instead of telephoning about some day-to-day issues would be acceptable as he would not have to directly deal with a clergywomen. However it is important to note that despite the fact that where explicit opposition was closed to conversation, the women were more likely to feel negatively about it (using terms such as 'nonsense'), this did not lead to them being any more likely to challenge or resist such treatment. The lack of willingness and ability to challenge or even to report the widespread discriminatory treatment they face has been discussed elsewhere (see Greene \& Robbins, 2015)

Some might say this demonstrates how the two different points of view can work effectively, but what this study demonstrates is that can only happen when mutual respect and effective communication are maintained and even then it can be difficult. The women seem 
to be reluctant to challenge the status quo, but rather to work with individuals among whom they minister.

\section{Doing ministry}

All the women agree that by their presence ministry is changing. Some are wary that they do not want to promote an 'all girls club' to replace what has been an 'all boys club' as Karen (ordained 2004) said:

I think a group of women, you know, single sex groupings are not good. End of. I think a bunch of women get petty. In a different way from a bunch of men.

There is the recognition that it is the balance that is important. A number of the women expressed the hope that their ministry was making ministry for men easier. Enabling them, perhaps, to be able to strike a better balance between their ministry and family life as Cathryn (ordained 1994) said:

I think perhaps there are a lot of [clergy] men who feel squashed into the competitive sort of mould... I don't see quite so much as I used to at clergy gatherings seeing men sort of showing off their full diaries, you know 'My diary is fuller than your diary'. You don't get that competitive edge now that you used to, from what I can remember. And I think that it's also giving some of the men, at any rate, permission to be human and open up.

\section{Summary}

It is evident from the themes that have emerged that the clergywomen are changing ministry through example and by enabling it to be done in different ways. The tension that emerges from this and from the different expressions of opposition to their ministry seem to be a significant part of creating this change. 
Katriona (ordained 2008) summarised this in the following way:

I think it is changing, yes, yeah. But it's a slow job, it's a slow job.

In 1998, Field wrote that the ordination of women in the Church of England would bring forth a new model of priesthood that transcended gender. However, it seems that the male model of priesthood is still very much alive and well, though being slowly chipped away by the numbers of women now in the role. The Church of England's recent moves toward appointment women bishops may begin to enable everyone to move forward together. What this study clearly demonstrates is that clergywomen have developed a ministry that is different and valued by many even if they do not agree they are doing things differently. When women bishops have been part of the Church of England for ten years perhaps the story will be different? 


\section{References}

Acker, J. (1990). Hierarchies, jobs, bodies: A theory of gendered organizations. Gender \& Society, 4(2), 139-158.

Acker, J. (2006). Inequality regimes: Gender, class, and race in organizations. Gender \& Society, 20(4), 441-464.

Advisory Council for the Church's Ministry (1991). Deacons Now: The report of a Church of England working party concerned with women in ordained ministry. London: ACCM.

Bagilhole, B. (2003). Not a glass ceiling more a lead roof: Experiences of pioneer women priests in the Church of England. Equal Opportunities International, 25 (2), 109-125

Bagilhole, B. (2006). Prospects for change? Structural, cultural and action dimensions of the careers of pioneer women priests in the Church of England. Gender Work and Organization, 10 (3), 361-377.

Cranmer, F (2012). Case law on church employment. Churches' Legislative Advisory Service. Church House: London.

Field, S.E. (1998). The contribution and challenge of women priests: The first years of ordained women's ministry in the Church of England. Unpublished MTh thesis in Applied Theology, University of Oxford.

Francis, L.J., \& Robbins, M. (1999). The Long Diaconate 1987-1994: Women deacons and the delayed journey to priesthood. Leominster: Gracewing.

Fullalove, B. (1987a). Ministry in the C of E (1919-70): Part 1. The Modern Churchman, 29(2), 35-44.

Fullalove, B. (1987b). Ministry in the C of E (1919-70): Part 2. The Modern Churchman, 29(3), 35-44.

Furlong, M. (1998). Act of Synod - Act of Folly? Canterbury Press: London.

Gill, S., (1994). Women and the Church of England: From the eighteenth century to the present. London: SPCK.

Greene, A., \& Robbins, M. (2015). The Cost of a Calling? Clergywomen and Work in the

Church of England. Gender, Work and Organization, 22, 405-420.

Hall, C. (1992) (Ed.). The Deacon's Ministry. Leominster: Gracewing.

Jones, I. (2004). Women and priesthood in the Church of England ten years on. London: Church House Publishing.

Martin, P. Y. (2003) 'Said and done' versus 'saying and doing': Gendering practices, practicing gender at work. Gender \& Society, 17(3), 342-66. 
McDuff, E.M. (2001). The gender paradox in work satisfaction and Protestant clergy. Sociology of Religion, 62, 1-21.

Murphy-Geiss, G.E. (2011). Married to the minister: The status of the clergy spouse as part of a two-person single career. Journal of Family Issues, 32(7), 932-955. doi: 10.1177/0192513X10396660.

Niemela, K. (2011). Female clergy as agents of religious change? Religons, 2, 358-371. doi: $10.3390 /$ rel2030358.

Peyton, N. \& Gatrell, C. (2013). Managing clergy lives: Obedience, sacrifice, intimacy. Bloomsbury: London.

Robbins, M. (2008). Clergywomen in the Church of England: A psychological study. Lampeter: Edwin Mellen.

Smith, J.A., Flowers, P., \& Larkin, M. (2009). Interpretative Phenomenological Analysis. London: Sage.

Stewart-Thomas, M. (2009). Gendered congregations, gendered service: The impact of clergy gender on congregational social service participation. Gender, Work \& Organization, 17(4), 406-432.

Treasure, C. (1991). Walking on Glass: Women deacons speak out. London: SPCK.

\footnotetext{
'Note: the two integrities which was created by the 1993 Act of Synod was rescinded in 2014.
} 